\title{
THE INFLAMMATORY AND HEMOSTATIC CARDIOVASCULAR RISK MARKERS DURING ACUTE HYPERGLYCEMIC CRISIS IN TYPE 1 AND TYPE 2 DIABETES
}

\author{
INFLAMATORNI I HEMOSTATSKI KARDIOVASKULARNI MARKERI RIZIKA \\ U TOKU AKUTNE HIPERGLIKEMSKE KRIZE U TIPU 1 I TIPU 2 DIJABETESA
}

\author{
Dragana Popovic ${ }^{1}$, Katarina Lalic ${ }^{1}$, Aleksandra Jotic ${ }^{1}$, Tanja Milicic ${ }^{1}$, Jelena Bogdanovic ${ }^{1}$, \\ Maja Đorđevic ${ }^{2}$, Sanja Stankovic ${ }^{3}$, Veljko Jeremic ${ }^{4}$, Nebojsa M. Lalic ${ }^{1}$ \\ ${ }^{1}$ Clinic for Endocrinology, Diabetes and Metabolic Diseases, Clinical Centre of Serbia, \\ Faculty of Medicine, University of Belgrade, Belgrade, Serbia \\ ${ }^{2}$ Emergency Center, Clinical Centar of Serbia, Clinical Center of Serbia, Belgrade, Serbia \\ ${ }^{3}$ Center for Medical Biochemistry, Clinical Center of Serbia, Belgrade, Serbia \\ ${ }^{4}$ Department for Operations Research and Statistics, Faculty of Organizational Sciences, \\ University of Belgrade, Belgrade, Serbia
}

\begin{abstract}
Summary
Background: We analyzed cardiovascular inflammatory (Creactive protein (CRP), interleukin 6 (IL-6)), haemostatic (homocysteine) risk markers in lean and obese patients at admission and acute hyperglicemic crisis (AHC) resolving, involving diabetic ketoacidosis (DKA) and hyperosmolar hyperglycemic state (HHS).

Methods: In that context, we included group $A: N=20$ obese, $B: N=20$ lean patients with DKA; $C: N=10$ obese, $D: N=10$ lean patients with HHS; $\mathrm{E}: \mathrm{N}=15$ obese, $\mathrm{F}: \mathrm{N}=15$ lean controls. CRP, IL-6, homocysteine were determined by ELISA. Results: Our results showed that CRP, IL-6, and homocysteine levels decreased in all groups: $(A: p<0.001 ; B$ : $p<0.001, C: p<0.05$; $D: p<0.001 \mathrm{mg} / \mathrm{L}),(A: p<0.001$ B: $p<0.001, C: p<0.001, D: p<0.01 \mathrm{pg} / \mathrm{mL}),(A: p<0.001$, B: $p<0.001 ; C: p<0.05, D: p=0.001 \mu \mathrm{mol} / \mathrm{L})$, respectively, at resolving $\mathrm{AHC}$. However, CRP persisted higher $(p<0.001, p<0.01)$, IL-6 lower $(p<0.05, p<0.001)$, while homocysteine levels turned out to be similar to controls.

Conclusions: AHC is associated with increased inflammatory and hemostatic cardiovascular risk markers. Also, insulin therapy in $\mathrm{AHC}$ has had more pronounced favorable effect on IL-6 and homocystein than on CRP.
\end{abstract}

Keywords: acute hyperglycemic crisis, cardiovascular risk markers, inflammatory markers, haemostatic markers

\section{Kratak sadržaj}

Uvod: Analizirali smo kardiovaskularne inflamatorne (Creaktivni protein (CRP), interleukin 6 (IL-6)) i (homocistein) hemotatske markere rizika u negojaznih i gojaznih pacijenata pri prijemu i razrešenju akutne hiperglikemijske krize (AHK), uključujući dijabetesnu ketoacidozu (DKA) i hiperosmolarno hiperglikemijsko stanje (HHS).

Metode: $U$ tom kontekstu uključili smo grupu $A: N=20$ gojaznih, $B: N=20$ negojaznih bolesnika sa DKA; $C: N=$ 10 gojaznih, $\mathrm{D}: \mathrm{N}=10$ negojaznih bolesnika sa HHS; $\mathrm{E}$ : $\mathrm{N}=15$ gojaznih, $\mathrm{F}: \mathrm{N}=15$ negojaznih kontrola. Nivo CRP, IL-6 i homocistein određeni su ELISA metodom.

Rezultati: Naši rezultati su pokazali niže nivoe CRP, IL-6 i homocisteina nakon rešavanja $A H K$ u poređenju sa prijemom u svim grupama: (A: $p<0,001$; $B: p<0,001, C$ : $p<0,05$; $D: p<0,001 \mathrm{mg} / \mathrm{L}),(A: p<0,001 \mathrm{~B}: \mathrm{p}<0,001$; C: $p<0,05, D: p=0,001 \mathrm{mmol} / \mathrm{L}),(A: p<0,001, B$ : $p<0,001, C: p<0,001, D: p<0,01 \mathrm{pg} / \mathrm{mL}$ ) nakon rešavanja AHK. Međutim, nivo CRP je ostao viši $(p<0,001$, $p<0,01)$, IL-6 niži $(p<0,05, p<0,001)$, dok je nivo homocisteina sličan u poređenju sa kontrolama.

Zaključak: AHK su povezane sa povišenim nivoom inflamatornih i hemostatičnih kardiovaskularnih markera rizika. Takođe, terapija insulinom u AHK ima značajno povoljniji efekat na nivo IL-6 i homocisteina, nego na nivo CRP.

Ključne reči: akutna hiperglikemijska kriza, inflamatorni markeri, hemotatski markeri

List of abbreviations: Acute hyperglicemic crisis, $\mathrm{AHC}$; diabetic ketoacidosis, DKA; hyperosmolar hyperglycemic state, HHS; type 1 diabetes, T1D; type 2 diabetes,T2D; C-reactive protein ,CRP; interleukin 6, IL-6; body mass index, BMI; glycated hemoglobin, HbA1c.

\author{
Address for correspondence: \\ Clinic for Endocrinology, Diabetes and Metabolic Diseases, \\ Clinical Center of Serbia \\ Dr Subotica, 13; 11000 Belgrade, Serbia \\ e-mail: nebojsa.m.lalic@gmail.com
}




\section{Introduction}

Acute hyperglicemic crisis (AHC) involving diabetic ketoacidosis (DKA) and hyperosmolar hyperglycemic state (HHS) are the most severe hyperglycemic metabolic impairments in patients with type 1 diabetes (T1D) and type 2 diabetes (T2D) (1).

Also, previous studies have shown that repeated hyperglycemic crises increase the cardiovascular risk markers. Previously, it was reported that novel cardiovascular risk biomarkers might be classified as follows: inflammatory (C-reactive protein (CRP), interleukin 6 (IL-6), etc), haemostatic (homocysteine, etc) and other markers. On the other hand, acute hyperglycemia is associated with inflammation and accelerates the inflammatory immune response (2). Simultaneously, it has been shown that hyperglycemia can induce proinflammatory cytokines genes in $T$ cells and acute phase reactants, CRP and IL-6 $(3,4)$. In addition, T2D and obesity are linked with increased levels of CRP and IL-6 $(2,5-9)$. Furthermore, elevated plasma homocysteine levels were associated with cardiovascular complications in diabetes (10-12). However, opposite findings regarding homocysteine levels in T2D have been demonstrated: increased (13), unchanged (14) or decreased (15) levels, respectively. In that context, the first study evaluated the level of inflammatory and haemostatic cardiovascular risk markers in AHC reported increase of these markers at admission in emergency care unit (16).

Therefore, the aim of this study was to analyze the changes in cardiovascular inflammatory (CRP and IL-6) and haemostatic (homocysteine) risk markers in lean and obese patients with $\mathrm{AHC}$.

\section{Materials and Methods}

\section{Patients/Research design}

The study included 90 subjects, 60 were diagnosed with DKA or HHS, whereas the control group consisted of 30 weight-matched control subjects. All included subjects were grouped as follows: 1) 20 obese patients with DKA; 2) 20 lean patients with DKA; 3) 10 obese patients with HHS; 4) 10 lean patients with HHS; 5) 15 obese control subjects and 6) 15 lean control subjects. The study included patients of both genders, 35 to 70 years of age. The study did not include either patients with manifested infection or any known precipitating illness for DKA or $\mathrm{HHS}$, or those with overt cardiovascular disease. DKA was defined on the basis of glycaemia $>13.9 \mathrm{mmol} / \mathrm{L}$, $\mathrm{pH}$ level $<7.3$, bicarbonate $>18 \mathrm{mmol} / \mathrm{L}$, anion gap $>15$ and positive ketonouria. HHS was defined on the basis of glycaemia $>22.4 \mathrm{mmol} / \mathrm{L}, \mathrm{pH}$ level $>$ 7.3 and bicarbonate $>18 \mathrm{mmol} / \mathrm{L}$. The criterion for the resolving of hyperglycemic state was the reduction of glycaemia $13.9 \mathrm{mmol} / \mathrm{L}$, elevation of the $\mathrm{pH}$ level $>7.3$, of bicarbonate $>18 \mathrm{mmol} / \mathrm{L}$, with anion gap normalisation (1). Each participant was subjected to:

a) anamnestic interview with defining of anthropometric measures: body weight (BW) and height $(\mathrm{H})$, while body mass index $(\mathrm{BMI})$ was calculated using the following formula: BMI $\left(\mathrm{kg} / \mathrm{m}^{2}\right)=$ BW $(\mathrm{kg}) / \mathrm{H}^{2}\left(\mathrm{~m}^{2}\right)$;

b) physical examination with measuring of body temperature;

c) Laboratory analyses: glycaemia, using the glucose oxidase test (Beckman Instruments, Fullerton, CA, USA), glycated hemoglobin (HbA1c) levels were determinated using turbidimetricimmunoassay for $\mathrm{HbA1c}$ (Boehringer Mannheim, Mannheim, Germany), $\mathrm{pH}$ of deoxigenated blood, bicarbonate, electrolytes, and other standard laboratory analyses in accordance with the criteria. All analyses were carried out during the same day and blood samples drawn by the same study nurse after a $12 \mathrm{~h}$ overnight fast and were stored at $-70{ }^{\circ} \mathrm{C}$ until assayed. The presence of diabetes was defined in accordance with the $\mathrm{WHO}$ definition, while the presence of obesity was determined on the basis of $B M I \geq 30 \mathrm{~kg} / \mathrm{m}^{2}(17,18)$.

The study included the following procedures:

1. Determining the levels of CRP ( $\mathrm{mg} / \mathrm{L})$ and homocysteine $(\mu \mathrm{mol} / \mathrm{L})$ by the ELISA method;

2 . Determining the level of proinflamatory cytokine IL-6 $(\mathrm{pg} / \mathrm{mL})$ using the ELISA method (ALPCO, Salem, NH, USA)

The high-sensitive $\mathrm{C}$-reactive protein (hs-CRP) serum concentrations were measured using commercial assays on Roche Cobas 6000 automated analyzer. Reference range for hs-CRP was $0-5 \mathrm{mg} / \mathrm{L}$. Homocysteine serum concentrations were measured using commercial assay on ADVIA Centaur System automated analyzer (Siemens, Manheim, Germany). Reference range for homocysteine for patients younger than or equal to 70 years was 4 to 14 $\mu \mathrm{mol} / \mathrm{L}$, and for patients older than 70 years 6 to 20 $\mu \mathrm{mol} / \mathrm{L}$. The coefficients of variation of the assays were all $5 \%$. The instrument calibrations for the assays were performed as recommended by the manufacturers and were within the specifications. The study was conducted in the Metabolic Unit of the Emergency Centre of the Clinical Centre of Serbia, with the permission of the Ethical Committee of the Faculty of Medicine, University of Belgrade, after patients or next of kin gave the informed consent to participate in the study.

All the patients were treated by intravenous insuline infusion according to the standard protocol (bolus dose $0.2 \mathrm{IU} / \mathrm{kg} \mathrm{BW}$, followed by $0.1 \mathrm{IU} / \mathrm{kg}$ BW/h)(1). 
Blood samples for defining the level of CRP,IL-6 and homocysteine were taken during the DKA and $\mathrm{HHS}$ at admission and 24 hours after the beginning of insulin therapy, upon resolving $\mathrm{AHC}$.

\section{Statistics}

Data are presented as mean \pm SD. Data were tested for normal distribution using KolmogorovSmirnov test. The appropriate descriptive and analytical methods (absolute and relative numbers, t test, Wilcoxon test, Mann-Whitney test) were used and the results were presented in the form of figures and tables. Data were analyzed using the Statistical Package for the Social Sciences (SPSS) software (Advanced Statistics, version 20.0), Chicago, IL. The $\mathrm{P}<0.05$ criterion was used in the testing procedure to calculate the significant difference level.

\section{Results}

The total number of investigated patients was 60 , among which 20 lean (between 23 to $49 \mathrm{yrs}$ ) and
20 obese DKA patients (between 30 to $53 \mathrm{yrs}$ ), and 10 lean (between 65 to $70 \mathrm{yrs}$ ) and 10 obese (between 58 to $70 \mathrm{yrs}$ ) HHS patients. The control groups consisted of 15 lean and 15 obese subjects, aged 35 to 70 , both males and females. BMI values ranged from 21.3 to $45.2 \mathrm{~kg} / \mathrm{m}^{2}$. None of the subjects reported simptoms or signs of infective diseases or other illness. Summary of baseline clinical characteristics of all participants included in the study is shown in Table I. Laboratory parameters of all patients at admission and after resolving $\mathrm{AHC}$ as well as baseline values for control subjects are presented in Table II. After insulin therapy was administrated, during the first $24 \mathrm{~h}$, levels of glycemia, bicarbonates and $\mathrm{pH}$ were corrected at resolving $\mathrm{AHC}, \mathrm{DKA}$ or $\mathrm{HHS}$.

\section{Inflammatory cardiovascular risk markers in acute hyperglicemic crises in diabetes}

In order to evaluate the status of cardiovascular risk markers in AHC, we determined the level of two parameters, CRP and IL-6, in obese and lean patients with DKA and HHS.

Table I Clinical characteristics of lean and obese patients with diabetic ketoacidosis (DKA) or hyperosmolar hyperglycemic state (HHS) and control subjects.

\begin{tabular}{|l|c|c|c|c|c|c|}
\hline Parameters & Lean DKA & Obese DKA & Lean HHS & Obese HHS & Lean control & Obese control \\
\hline Patients $(\mathrm{n})$ & 20 & 20 & 10 & 10 & 15 & 15 \\
\hline Age $(\mathrm{yrs})$ & $39 \pm 1.23$ & $43.1 \pm 1.29$ & $68 \pm 0.71$ & $63.7 \pm 1.15$ & $45 \pm 3.05$ & $47.13 \pm 1.91$ \\
\hline Sex $(\mathrm{M} / \mathrm{F})$ & $7 / 13$ & $6 / 14$ & $3 / 7$ & $5 / 5$ & $4 / 11$ & $7 / 8$ \\
\hline $\mathrm{BMl}\left(\mathrm{kg} / \mathrm{m}^{2}\right)$ & $22.84 \pm 0.88$ & $31.69 \pm 0.19$ & $21.31 \pm 0.47$ & $31.33 \pm 0.31$ & $28.09 \pm 0.30$ & $45.52 \pm 0.93$ \\
\hline $\mathrm{HbA} 1 \mathrm{c}(\%)$ & $10.89 \pm 0.34$ & $10.75 \pm 0.41$ & $7.99 \pm 0.21$ & $8.16 \pm 0.22$ & $5.49 \pm 0.12$ & $5.8 \pm 0.08$ \\
$\mathrm{Hb}(\mathrm{mmol} / \mathrm{mol})$ & $90.35 \pm 5.45$ & $93.9 \pm 4.53$ & $63.84 \pm 2.34$ & $65.69 \pm 2.36$ & $36.51 \pm 1.30$ & $39.9 \pm 0.86$ \\
\hline
\end{tabular}

Data are means $\pm \mathrm{SE}$.

Table II Laboratory parameters of lean and obese patients with diabetic ketoacidosis (DKA), or hyperosmolar hyperglycemic state (HHS) and control subjects at admission and after resolving $\mathrm{AHC}$.

\begin{tabular}{|l|c|c|c|c|c|}
\hline & Obese DKA & & Obese HHS & & Control \\
\hline Parameters & Admission & Resolving AHC & Admission & Resolving AHC & \\
\hline Glycemia $(\mathrm{mmol} / \mathrm{L})$ & $34.08 \pm 3.60$ & $12.79 \pm 1.21^{*}$ & $27.00 \pm 1.28$ & $13.88 \pm 0.79 *$ & $4.83 \pm 0.13$ \\
\hline $\mathrm{pH}$ & $7.06 \pm 0.02$ & $7.34 \pm 0.01^{*}$ & $7.38 \pm 0.02$ & $7.42 \pm 0.01 \#$ & $7.40 \pm 0.01$ \\
\hline $\mathrm{HCO}_{3}(\mathrm{mmol} / \mathrm{L})$ & $5.24 \pm 0.54$ & $17.63 \pm 0.77^{*}$ & $22.91 \pm 0.96$ & $24.33 \pm 0.22$ & $21.55 \pm 0.33$ \\
\hline & Lean DKA & & Lean HHS & & Control \\
\hline $\mathrm{Glycemia}(\mathrm{mmol} / \mathrm{L})^{37.26 \pm 3.71}$ & $12.75 \pm 0.89 *$ & $30.91 \pm 2.53$ & $14.04 \pm 0.70^{*}$ & $4.65 \pm 0.24$ \\
\hline $\mathrm{pH}$ & $7.02 \pm 0.03 \$$ & $7.34 \pm 0.02 * \$$ & $7.41 \pm 0.01$ & $7.42 \pm 0.01$ & $7.41 \pm 0.01$ \\
\hline $\mathrm{HCO}_{3}(\mathrm{mmol} / \mathrm{L})$ & $4.90 \pm 0.57 \$$ & $21.88 \pm 0.49 * \$$ & $21.61 \pm 0.46$ & $24.46 \pm 0.21^{*}$ & $20.91 \pm 0.26$ \\
\hline
\end{tabular}

Data are means $\pm \mathrm{SE}$. ${ }^{*} \mathrm{P}<0.01$ vs. admission value of each group, ${ }^{\#} \mathrm{P}<0.05$ vs. admission value of each group, $\mathrm{P}<0.01$ vs. obese HHS value, a $\mathrm{P}<0.01$ vs. obese HHS value, ${ }^{b} \mathrm{P}<0.01$ vs. obese DKA value, $\$ \mathrm{P}<0.01$ vs. lean $\mathrm{HHS}$ value 


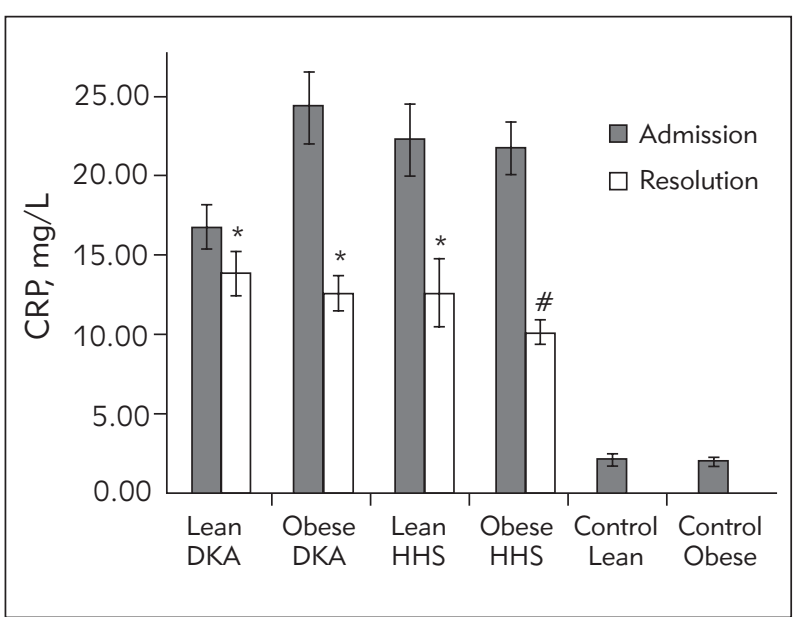

Figure 1 The levels of $\mathrm{C}$-reactive protein (CRP) measured in plasma in obese and lean patients with diabetic ketoacidosis (DKA), or hyperosmolar hyperglycemic state (HHS), and control subjects at admission and after resolving AHC. The bar graphs show the means \pm SD for each of the patient groups. The levels of CRP were significantly lower at resolving AHC vs admission in both lean and obese patients with DKA and HHS. The levels of CRP were significantly higher in obese and lean patients with DKA and HHS, vs control subjects $\left({ }^{*} \mathrm{p}<0.001, \# \mathrm{p}<0.05\right)$.

When we analyzed the level of cardiovascular risk marker CRP, we found that the level of CRP was significantly decreased at resolving $A H C$ in comparison to moment of admission in both lean and obese patients with DKA and HHS (lean DKA: $16.77 \pm 6.12$ vs. $13.86 \pm 6.28$, p 0.001 ; obese DKA: $24.26 \pm$ 10.16 vs. $12.63 \pm 4.88$, p 0.001 ; lean HHS: 22.25 \pm 7.09 vs $12.64 \pm 6.74$, p 0.001 ; obese HHS: 21.7 \pm 5.03 vs $10.26 \pm 2.48$, p $0.05, \mathrm{mg} / \mathrm{L}$, respectively) (Figure 1). Yet, the resolving AHC levels of CRP, in both obese and lean patients with DKA and HHS were significantly higher compared with control subjects (obese controls $2.14 \pm 0.93$, lean controls $2.20 \pm$ 1.59)(HHS $p<0.01$, DKA $p<0.001$ ) (Figure 1).

In addition, we determined interleukin 6 (IL-6) in obese and lean patients with diabetic ketoacidosis (DKA), or hyperosmolar hyperglycemic state (HHS), and control subjects at admission and after resolving $\mathrm{AHC}$.

We found that the levels of IL-6 were significantly decreased at resolving $\mathrm{AHC}$ in comparison to moment of admission in both lean and obese patients with DKA and HHS (lean DKA: $37.73 \pm 11.24$ vs. $28.70 \pm 9.45$, p 0.001; obese DKA: $53.94 \pm 89.38$ vs. $33.31 \pm 83.79$, p 0.001 ; lean HHS: $107.23 \pm$ 86.29 vs. $75.79 \pm 45.14$, p 0.01; obese HHS: $84.73 \pm 98.66$ vs. $36.60 \pm 39.81, \mathrm{p} 0.001, \mathrm{pg} / \mathrm{mL}$, respectively) (Figure 2). Still, the resolving AHC levels of IL-6, did not differ significantly among groups, and were lower compared with control subjects (obese control $79.70 \pm 6.86$, lean control $78.06 \pm 4.85$

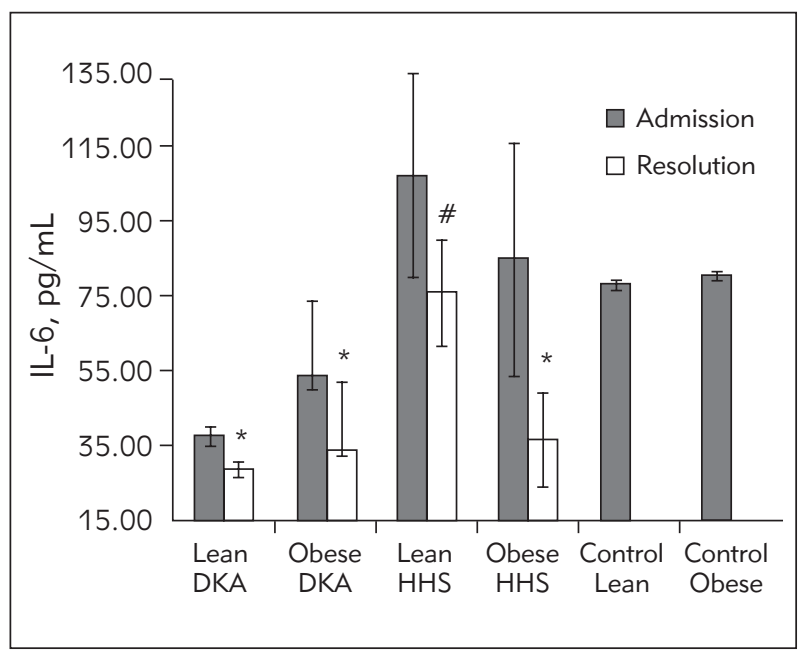

Figure 2 The level of interleukin 6 (IL-6) measured in plas$m a$ in obese and lean patients with diabetic ketoacidosis (DKA) or hyperosmolar hyperglycemic state (HHS), and control subjects at admission and after resolving AHC. The bar graphs show the means \pm SD for each of the patient groups. The levels of IL- 6 was significantly decreased at resolving AHC vs admission in both lean and obese patients with DKA and HHS. Moreover, the resolving AHC levels of IL-6 in lean patients HHS did not differ vs control subjects, while all other groups had lower levels vs control subjects.

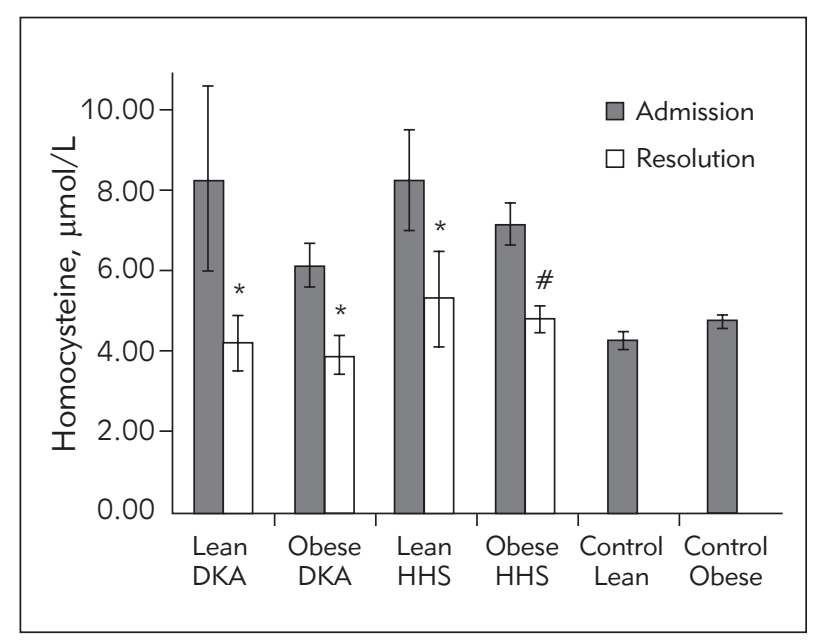

Figure 3 The level of homocysteine measured in plasma in obese and lean patients with diabetic ketoacidosis (DKA) or hyperosmolar hyperglycemic state (HHS), and control subjects at admission and after resolving $\mathrm{AHC}$. The bar graphs show the means \pm SD for each of the patient groups. The levels of homocysteine were significantly decreased at resolving $\mathrm{AHC}$ vs admission in both lean and obese patients with DKA and HHS. Moreover, the resolving AHC levels of homocysteine, in both obese and lean patients with DKA and HHS did not differ vs control subjects.

$\mathrm{pg} / \mathrm{mL}$ ) (HHS obese $\mathrm{p}<0.001$, DKA $\mathrm{p}<0.05$ ) (Figure 2), whereas in lean patients with HHS there was no significant difference compared with control subjects $(p>0.05)$. 
Haemostatic cardiovascular risk marker in acute hyperglicemic crises in diabetes

When we evaluated the level of third investigated cardiovascular risk marker homocysteine, we found that the level of homocysteine was significantly decreased at resolving $\mathrm{AHC}$ than at admission in both lean and obese patients with DKA and HHS (lean DKA: $8.25 \pm 10.32$ vs. $4.19 \pm 3.02$, p 0.001; obese DKA: $6.14 \pm 2.41$ vs. $3.88 \pm 2.17$, p 0.001 ; lean HHS: $8.25 \pm 3.92$ vs. $5.31 \pm 3.75, p=0.001$; obese HHS: $7.16 \pm 1.62$ vs. $4.79 \pm 1.07$, p 0.05, $\mu \mathrm{mol} / \mathrm{L}$, respectively) (Figure 3). Moreover, the resolving $\mathrm{AHC}$ levels of homocysteine in both obese and lean patients with DKA and HHS did not differ compared to control subjects (obese controls $4.74 \pm 0.59$ lean controls $4.26 \pm 0.77 \mu \mathrm{mol} / \mathrm{L})(p>0.05)$ (Figure 3).

\section{Discussion}

We have analyzed the level of cardivascular risk markers (CRP, IL-6, homocystein) before and 24 hours after the onset of $\mathrm{AHC}$ and adequate insulin therapy in obese and lean patients with DKA and HHS, without overt infections, cardiovascular disease or trauma. Our results have shown that in patients with $\mathrm{AHC}$, the levels of inflammatory and hemostatic markers of cardivascular risk were increased at admission, while after the management of hyperglycemic crisis with intensified insulin therapy, these values of these markers significantly decreased, implying the decrease of the cardiovascular risk. The obtained results are in accordance with the previous findings, suggesting the beneficial antiinflamatory effect of insulin $(5,19-21)$.

It is well known that not only in chronic hyperglycemia but also in intermittent hyperglycemic crisis, the levels of inflammatory and haemostatic cardiovascular risk biomarkers were impaired (22). However, previously it was demonstrated in animal models that the repetitive acute hyperglycemia represents a risk factor for initiation and progression of atherosclerosis independently of other metabolic factors, such as insulin resistance and dislipidemia (23).

When we evaluated the levels of inflammatory cardiovascular risk marker CRP, we found that the level of CRP was significantly decreased at resolving AHC than at admission in both lean and obese patients with DKA and HHS, but still higher than the level determined in control subjects.

Previously, it has been shown that the level of CRP was associated with T2D via insulin resistance (24), and that it correlated with $\mathrm{HbA} 1 \mathrm{c}$ in nondiabetics (25), while higher HbA1c in diabetes was found to be associated with elevation of CRP (19). Our patients had unsatisfactory metabolic control before acute decompensation, suggesting chronic state of hyperglycemia and long-term low-grade inflama- tion, probably leading to the slowest recovering of CRP levels. Some other data suggested that the level of CRP started to fall only after 5 days after insulin therapy had been initiated in intensive care unit (9). Also, this marker might reflect the long term cardiovascular risk still existing after resolving of the AHC.

In addition, we measured IL-6 levels in obese and lean patients with DKA, or HHS, and in control subjects at admission and after resolving $\mathrm{AHC}$. We found that the levels of IL- 6 were significantly decreased at resolving $\mathrm{AHC}$ than at admission, in both lean and obese patients with DKA and HHS, following the implementation of insulin therapy which exerted a potent IL-6 lowering effect. Still, the IL-6 levels at resolving of AHC levels in lean HHS patients were similar to control subjects, whereas in all other groups, they were lower than in control subjects.

It is well known that acute hyperglycemia can significantly increase the inflammatory cytokines in the peripheral circulation, and that it plays important roles in immune system activation in diabetes $(1,26$, 27). Previously, it was documented that the patients with DKA have the activation of T-cells caused by increased level of oxidative stress $(3,28)$. Moreover, circulating levels of IL- 6 were increased, but there was downregulation of antiinflammatory cytokine production in T2D. Furthermore, circulating blood cells have the capacity to produce cytokines in diabetes which contribute to the augmented acutephase response, but the main source of the increased plasma IL-6 concentrations may be from non-circulating cells (29). Additionally, previous studies have shown that higher IL-6 can affect the signaling pathways of the insulin receptor in adipose tissue (30).

Simultaneously, further investigations have shown that IL-6 was significantly elevated in patients with hyperglycemic crises and were significantly decreased after insulin treatment, although levels in remission remained higher than in controls, in contrast to our results $(31,32)$. We speculate that this difference may be due to the previously described heterogeneity of IL-6 sources and effects. Increased levels of IL-6 levels in patients with AHC may decrease expression of PPAR- $\gamma$ (29), interfering with phosphorylation of insulin receptors in peripheral tissue, affecting insulin signaling, (32) and increasing the expression of cell adhesion molecules that are involved in endothelial cell damage and increased risk for cardiovascular event. Moreover, IL-6 released from monocytes during the state of hyperglycemia could upregulate PKC, through p38MAPK and NF- B, resulting in increased mRNA and protein for IL-6, thus amplifying its own effect (33).

On the other hand, previous data suggested the effect of obesity on the level of IL-6, implicating that obese patients with T2D have higher levels of IL-6 than nonobese T2D patients. Also, insulin therapy tends to counter this marker of inflammation, but the 
response is delayed in obese diabetics. Additionally, after $24 \mathrm{~h}$ of insulin administration to nonobese diabetic patients, a high-magnitude decrease of IL-6 was detected (34). In our study, lean HHS had higher levels of IL-6, at resolution of ACS, than other groups, i.e. their responce on insulin therapy was blunted, irrespective the absence of obesity. Interestingly, lean HHS patients had the highest level of IL- 6 among the groups innitially, at admision. It might be that acute hyperglycemia in this group compared to obese HHS, has domminant influence on inflammation, and consequently on IL-6 levels, which could be the background for its delayed responce to insulin therapy. Moreover, in some investigations it was suggested that the IL-6 gene has functional variants, some of which are associated with high IL-6 circulating levels and cardiovacular risk in patient with proinflammatory states (35).

When we analysed the level of third investigated cardiovascular risk marker homocysteine, we found that the levels of homocysteine were lower at resolving $\mathrm{AHC}$ than at admission in both lean and obese patients with DKA and HHS. Moreover, the resolving $\mathrm{AHC}$ levels of homocysteine, in both obese and lean patients with DKA and HHS, did not differ compared to control subjects. These data are not in line with the previously published results $(16,36)$, where homocysteine levels were not reduced promptly by intensified insulin therapy. On the other hand, it is reported that the level of homocysteine is influenced by many factors, including different drugs (37), which might devaluate its role as a marker of cardiovascular risk.

In addition, the compared groups differ in gender due to the fact that the absolute number of women is higher than men, but without statistical difference among groups. In that context, the current literature suggests different findings, higher levels of CRP and IL-6 in women (38) together with the absence of difference in the level of homocysteine between the sexes $(39,40)$. On the other hand, we analyzed patients in states of acute metabolic decompensation, and we did not include either patients with manifested infection or any known precipitating illness for DKA or HHS, or those with overt cardiovascular disease, which would increase the level of our markers. Moreover, the scope of our study was not the difference in levels of these markers between sexes.

Finally, there are some limitations of our study, regarding the relatively small number of patients in investigated groups. However, the statistical significances among the groups that we obtained were based on non-parametric tests, which are more precise than parametric test, for small samples (41). Future direction in our investigation will be to include more patients in each group which will be the added value of our research.

Our study confirmed that $\mathrm{AHC}$, which involved in our investigation DKA and HHS, is associated with increased levels of inflammatory and hemostatic cardivascular risk markers, irrespective of diabetes type or presence of obesity. We speculate that repetitive $\mathrm{AHC}$ may play important role, amplyfing the risk factor for cardiovascular diseases. In addition, the normalization of them can be obtained by intensive insulin therapy, which appears to be based on the strong antiinflammatory effect of insulin. Moreover, our results imply that insulin therapy in these metabolic impairements has stronger beneficial effect on IL-6 and homocystein, than on CRP.

\section{Conflict of interest statement}

The authors stated that they have no conflicts of interest regarding the publication of this article.

\section{References}

1. Kitabachi AE, Umpierrez GE, Miles JM, Fisher JN. Hyperglycemic Crises in Adult Patients With Diabetes. Diabetes Care 2009; (32): 1335-43.

2. Pop D, D dârlat A, Zdrenghea D. Novel cardiovascular risk markers in women with ischaemic heart disease. Cardiovasc J Afr 2014; (25): 137-41.

3. Kitabchi AE, Umpierrez GE. Diabetic ketoacidosis anduces in vivo activation of human T-lymphocytes. Biochem and Biophys Res Commun 2004; (315): 404-7.

4. Gogos CA, Giali S, Paliogianni F, Dimitracopoulos G, Bassaris HP, Vagenakis AG. Interleukin-6 and C-reactive protein as early markers of sepsis in patients with diabetic ketoacidosis or hyperosmosis. Diabetologia 2001; (44): 1011-4.

5. Aljada A, Ghanim H, Mohanty P, Kapur N, Dandona P. Insulin inhibits the pro-inflamatory transcription factor early growth response gene-1 (Erg)-1 expression in mononuclear cells (MNC) and reduces plasma tissue factor (TF) and plasminogen activator inhibitor-1 (PAI-1) concentrations. J Clin Endocrinol Metab 2002; (87): 1419-22.

6. Barzilay JI, Freedland ES. Inflammation and its relationship to insulin resistance, type 2 diabetes mellitus and endothelial dysfunction. Metabol Syndrome Related Dis 2003; (1): 155-167.

7. Dalton RR, Hoffman WH, Passmore GG, Lee AMS. Plasma C-Reactive Protein Levels in severe Diabetic Ketoacidosis. Annals of Clinical Laboratory Science 2003; (33): 435-42. 
8. Collinson P. Laboratory medicine is faced with the evolution of medical practice. J Med Biochem 2017; 36: 2115.

9. Hansen TK, Thiel S, Wouters PJ, Christisnsen JS, Van den Berghe $\mathrm{G}$. Intensive insulin therapy exarts anti-inflamatory effects in critically ill patients and counteracts the adverse effect of low mannose-binding lectin level. J Clin Endocrinol Metab 2003; (88): 1082-8.

10. Meigs JB, Jacques PF, Selhub J, Singer DE, Nathan DM, et al. Fasting plasma homocysteine levels in the insulin resistance syndrome - the Framingham offspring study. Diabetes Care 2001; (24): 1403-10.

11. Huang $T$, Jing Jing R, Huang J, Li D. Association of homocysteine with type 2 diabetes: a meta-analysis implementing Mendelian randomization approach. BMC Genomics 2013; (14): 867.

12. Buysschaert $M$, Dramais AS, Wallemacq PE, Hermans MP. Hyperhomocysteinemia in type 2 diabetes: relationship to macroangiopathy, nephropathy, and insulin resistance. Diabetes Care 2000; (23): 1816-22.

13. Baldane S, Kendir Cl, Kirac OC, Ipekci S, Tekin G, Unlu A, Kebapcilar L. Effects of glucose ingestion on serum fractalkine levels in healthy subjects and newly diagnosed type 2 diabetic patients J Med Biochem 2018; 37: 3738.

14. Folsom AR, Nieto FJ, Mc Govern PG, Tsai MY, Malinow $M R$, et al. Prospective study of coronary heart disease incidence in relation to fasting total homocysteine, related genetic polymorphisms, and B vitamins: the Atherosclerosis Risk in Communities (ARIC) study. Circulation 1998; (98): 204-10.

15. Mazza A, Bossone E, Mazza F, Distante A. Reduced serum homocysteine levels in type 2 diabetes. Nutr Metab Cardiovasc Dis 2005; (15):118-24.

16. Stentz FB, Guillermo EU, Cuervo R, Kitabachi AE. Proinflammatory cytokines, markers of casrdiovascular risks, oxidative stress, and lipid peroxidation in patients with hyperglicemic crises. Diabetes 2004; (53): 2079-86.

17. World Health Org. Obesity: preventing and managing the global epidemic Report of a WHO Consultation (WHO Technical Report Series 894), 2006.

18. World Health Organization. Definition and Diagnosis of Diabetes Mellitus and Intermediate Hyperglycemia: Report of a WHO/IDF Consultation. Geneva, 2006.

19. King DE, Marnous AG, Buchanan TA, Pearson WS. CReactive Protein and Glycemic Control in Adults With Diabetes. Diabetes Care 2003; (53): 1535-9.

20. Li J, Huang $M$, Shen X. The association of oxidative stress and pro-inflammatory cytokines in diabetic patients with hyperglycemic crisis. Journal of Diabetes and Its Complications 2014; (28): 662-6.

21. Dandona P, Chaudhuri A, Ghanim H, Mohanty P. Insulin as an anti-inflammatory and antiatherogenic modulator. Journal of the American College of Cardiology 2009; (53):14-20.

22. Rolla A. The pathophysiological basis for intensive insulin replacement. Int J Obes Relat Metab Disord 2004; (28): S3-7.
23. Shuto $Y$, Asail A, Nagao M, Sugihara H, Oikawa S. Repetitive Glucose Spikes Accelerate Atherosclerotic Lesion Formation in C57BL/6 Mice. PLoS One 2015; (10): e0136840.

24. Pradhan AD, Manson JE, Rifai N, Buring JE, Ridker PM. C-reactive protein, interleukin-6, and risk of developing type 2 diabetes mellitus. JAMA 2001, (286): 327-34.

25. Wu T, Dorn JP, Donahue RP, Sempos CT, Trevisan M. Associations of serum $\mathrm{C}$-reactive protein with fasting insulin, glucose, and glycosylated hemoglobin. Am J Epidemiol 2002; (155): 65-71.

26. Ceriello A. Acute hyperglycaemia: a 'new' risk factor during myocardial infarction. European Heart Journal 2005; (26): 328-31.

27. Hoffman WH, Burek CL, Waller JL, Fisher LE, Khichi JM, Mellicke LB. Cytokine response to diabetic ketoacidosis and its treatment. Clinical Immunology 2003; (108): 175-81.

28. Stentz FB, Abbas E, Kitabachi AE. Hyperglycemiainduced activation of human T-lymphocytes with de novo emergence of insulin receptors and generation of reactive oxygen species. Biochemical and Biophysical Research Communications 2005; (335): 491-5.

29. Pickup JC, Chusney GD, Thomas SM, Burt D. Plasma interleukin-6, tumour necrosis factor and blood cytokine production in type 2 diabetes. Life Sciences 2000; (67): 291-300.

30. Hube $F$, Hauner $H$. The two tumor necrosis factor receptors mediate opposite effects on differentiation and glucose metabolism in human adipocytes in primary culture. Endocrinology 2000; (141): 2582-8.

31. Esposito K, Nappo F, Marfella R, Giugliano G, Giugliano F, Ciotola $M$, et al. Inflammatory cytokine concentrations are acutely increased by hyperglycemia in humans: role of oxidative stress. Circulation 2002; (106): 2067-72.

32. Kolb $\mathrm{H}$, Mandrup-Poulsen T. An immune origin of type 2 diabetes? Diabetologia 2005; (48):1038-50.

33. Devaraj S, Venugopal SK, Singh U, Jialal I. Hyperglycemia Induces Monocytic Release of Interleukin-6 via Induction of Protein Kinase C- $\alpha$ and $-\beta$. Diabetes 2005; (54): 85-91.

34. Goyal R, Faizy AF, Siddiqui SS, Singhai M. Evaluation of TNF- and IL-6 Levels in Obese and Non-obese Diabetics: Pre- and Postinsulin Effects. N Am J Med Sci. 2012; (4): 180-4.

35. Liu Y, Berthier-Schaad Y, Fallin MD, Fink NE, Tracy RP, Klag MJ, Smith MW, Coresh J. IL-6 Haplotypes, Inflammation, and Risk for Cardiovascular Disease in a Multiethnic Dialysis Cohort. J Am Soc Nephrol 2006; 17: 863-70.

36. Fonseca V, Madeline S, Schmidt B, Fink L, Kern P, Henry $R$. Plasma homocysteine concentration are regulated by acute hyperinsulinemia in nondiabetic but not type 2 diabetic subjects. Metabolism 1998; (47): 686-9.

37. Desanza C, Keebler M, Mc Namara D, Fonseca V. Drugs affecting homocysteine metabolism interaction on cardiovascular. Drugs 2002; (62):605-16. 
38. Thorand B. Baumer J, Kolb H, Meisinger C, Chambless $L$, Koenig W. et al. Sex Differences in the Prediction of Type 2 Diabetes by Inflammatory Markers. Results from the MONICA/KORA Augsburg case-cohort study, 19842002. Diabetes Care 2007 Apr; 30(4): 854-60.

39. Fukagawa NK, Martin JM, Wurthmann A, Prue $A H$, Ebenstein D, O'Rourkel B. Sex-related differences in methionine metabolism and plasma homocysteine concentrations. The American Journal of Clinical Nutrition 2000; (72): 22-9.
40. Hamin Reza Nakhai Pour HK, Grobbee DE, Muller M., Emmelot-Vonk M. and Yvonne T van der Schouw. Serum sex hormone and plasma homocysteine levels in middleaged and elderly men. European Journal of Endocrinology 2006; (155): 887-93.

41. De Winter, J. C. Using the Student's t-test with extremely small sample sizes. Practical Assessment, Research \& Evaluation, 2013; (10): 18.

Received: April 3, 2018

Accepted: June 5, 2018 